\title{
Competition and cooperation between fintech companies and traditional financial institutions
}

\author{
Anatoly Suprun*, Tetiana Petrishina, and Iryna Vasylchuk \\ Kryvyi Rih Economic Institute of Kyiv National Economic University named after Vadym Hetman, Kryvyi Rih, 50000, Ukraine
}

\begin{abstract}
The modern world is changing rapidly under the influence of digital technologies. This also applies to the financial sector of the economy. Since the mid-2000s, new fintech companies have entered the market. These companies are using new technologies to improve existing and create new financial services. In the course of their development, the interests of new market entrants often overlap with those of traditional participants, mainly banks. Investigation of the relations between fintech companies and traditional financial institutions gives an opportunity to form an idea of the financial picture of the near future. The research of the relations between fintech companies and traditional financial institutions gives an opportunity to form an idea of the financial picture of the near future. The article considers both aspects of competition and aspects of possible cooperation between financial market participants in a digital economy. The results of the scientific research demonstrate that cooperation will prevail over the competition. Probably existing financial institutions will reformat their architecture and become digital ones at the core.
\end{abstract}

\section{Introduction}

The digital economy is changing all aspects of socioeconomic life. Changes are happening fast, they are global in nature and ones have new opportunities, but ones also generate new risks. New technologies make financial services more accessible to the general public. But on the other hand, the number of available financial services and their complexity is increasing. New risks are generated, including new forms of financial fraud. The financial sector reflects the changes that are associated with digitalization very clearly, as manifested through the formation of new market entrants - fintech companies. There are relations between new and traditional financial market participants that are not simple. These relations may take the form of competition or cooperation. Fintech companies need to search for new niches and offer something that may interest demanding consumer in order to avoid competition from powerful banks. Such issues are important to society: competition must not be destructive, and the market must not be chaotic. Of course, the best form of relations is cooperation in which market participants will complement each other and society will benefit most.

\section{The current state of the fintech industry in the world}

A fintech company can be defined as a company that uses the latest digital technologies to improve its financial performance.

Fintech companies, as a separate phenomenon in the financial world, have begun to develop actively after the events of the global financial crisis of 2007-2009.

This was facilitated by sharp decline in confidence in traditional financial institutions and the rapid development of digital technologies. It was this period that the first digital currency bitcoin appeared. It is based on blockchain technology.

The fintech companies' formation, as a new sector of business, has led to interest from investors, but investment activity was uneven (Figure 1).

The peak of investment is observed in 2018, after a significant drop in 2017. According to the interim report [2] in the global fintech sector, the first half of 2019 is characterized by a downward trend at the end of the six months caused by a decrease in the number of large deals compared to 2018 .

Funding in the global fintech market has been slower in the first half of 2019: 962 deals totaling \$37.9 billion were recorded in the sector.

Private equity firms remain active. They initiated 35 deals worth $\$ 1.9$ billion in the first half of the year. The largest deals from 2019 to the present date were major mergers, acquisitions and buybacks, including: buyout of Dun \& Bradstreet company for $\$ 6.9$ billion from the U.S.; buyout of Concardis company for $\$ 6$ billion from Germany; buyout of eFront company for $\$ 1.3$ billion from France. Other important deals are expected to be completed soon, including the Fidelity's acquisition of Worldpay ( $\$ 43$ billion), the Fiserv's acquisition of First Data by ( $\$ 22$ billion), and the merger of Global Payments with Total System Services (\$21,5 billion). Merger operations certainly improve investment statistics but do not increase the segment.

\footnotetext{
* Corresponding author: suprun aa $@$ kneu.dp.ua
} 


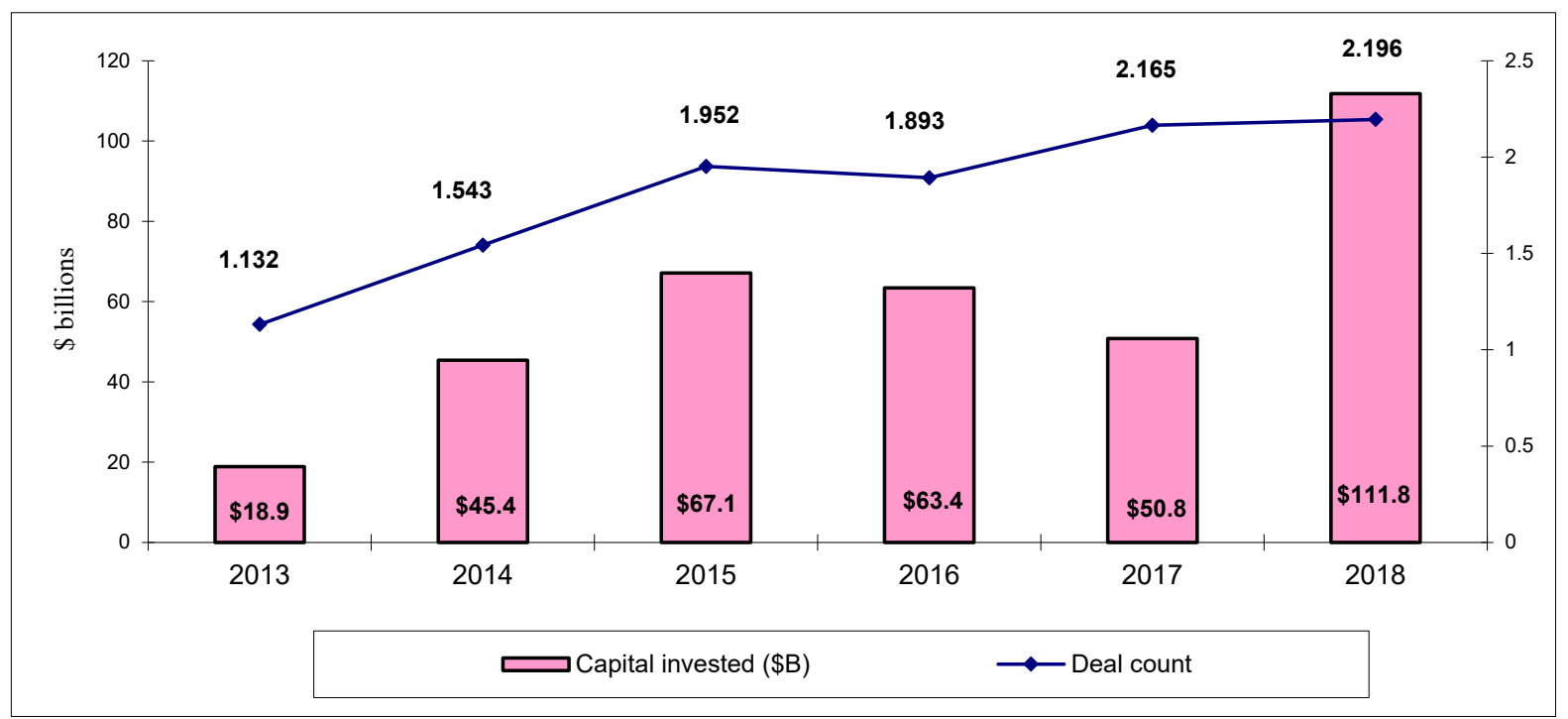

Fig. 1. Total investment activity (VC, PE and M\&A) in fintech 2013-2018 [1].

In the first half of 2019, investment in the global fintech market slumped from $\$ 120$ billion in 2018 to $\$ 37.9$ billion as of mid-2019. Corporate venture investments, which reached an impressive $\$ 25.3$ billion in 2018 , plummeted to $\$ 4.75$ billion in the first half of 2019. The main reason for this trend is that now corporations refrain from mega deals.

As in 2018, private equity companies' investments were insignificant due to low fintech market readiness and limited investment in industry leaders. Global private equity investments in the sector exceed $\$ 1.9$ billion in the first half of the year.

From the beginning of the year, there was sharp drop in investment from $\$ 5$ billion (which have generated 586 deals in 2018), to $\$ 1$ billion (ones have brought 171 deals in the first half of 2019) in blockchain and cryptocurrency sector. Over the 6 months of 2019, investment in insurtech has sharply declined as a result of funding drop in the early stage.

Total insurtech investment fell from $\$ 7.6$ billion in 2018 to $\$ 1.1$ billion in the first half of 2019 .

Fintech investment in Asia Pacific got off to a modest start in 2019 (only 102 deals worth $\$ 3.6$ billion) after experiencing a record-shattering level of investment in 2018 [3].

The results of investment activity in 2019 can be explained by the following:

- investors are worried about the emergence of the global financial crisis in 2020-2021 and prefer liquidity over profitability;

- the leading companies in the fintech industry still have little their own funds to invest in development;

- the market is unstructured and products under development are often unclear to a wide range of investors;

- blockchain technology has not proven to be enough flexible to implement in many business processes;

- there were a lot of informational reports about failed projects in the field of fintech in 2018-2019. This can be illustrated by the example of the powerful Chinese Ping An Insurance Company. Chinese Ping An insurer has planned large-scale investments in various technologies, from artificial intelligence to blockchain, for the amount of \$22 billion. The Ping An Insurance and Financial Group earns most of its money from the implementation of pension, savings, medical, and property insurance policies.

The group's technology development policy is investing in various startups. They will provide operational processes for the company.

There are a lot of projects and directions but not all of them are successful. For example, online health insurance provider called Good Doctor, which Ping An invested in 2018, is losing money. Autohome auto insurance provider, has lost about a quarter of its value since reaching its peak in May 2019. The Lufax capital management platform is having problems getting into an IPO. FinTech OneConnect has similar problems. A lot of money has invested in its activities too. Despite huge investments, Ping An's technology divisions have been accounted for only $3.8 \%$ of operating revenues, while implementation costs increased by $7 \%[4]$.

Insurers (except Chinese) are a lot less invested in technology than commercial banks. The insurance service has greater elasticity and often passive demand. Therefore, it is possible to automate insurance, to carrying it through mobile apps or with the robots' help only in certain directions (for example, On mandatory civil and legal liability insurance for motor vehicles owners).

The work of insurance mediators (agents and brokers) is required in voluntary insurance with flexible terms. Related insurance services will be transformed with new technologies. For example, programs like Audatex (preparation the cost estimates for repairing) or Auto Crash (assessment of cars which were damaged in a traffic incident), crash photo-, video simulation programs can virtually eliminate the institute's emergency commissariat. Programs are aimed at personalizing the insurance service and, accordingly, setting individual insurance rates can revolutionize insurance. These are telematics programs in auto insurance (Pay-As-You-Drive and Pay-How-YouDrive programs), risk assessment in personal insurance based on data analysis using Big Data. Future insurance is 
a tariffs reduction through maximum personalization. But sales will depend on the work of agents and brokers.

There are also changes in the area of private investment. They are related to the emergence of robotics consultants who build an investment portfolio based on the client's risk attitude. Large investment companies often offer their clients the services of a robotics consultant as an additional and free of charge to ordinary brokerage services. Investors probably will be divided into those who prefer machine maintenance and those who will need human services. This will be in the plane of mentality, psychology and age qualification (Generation X will select people, and Generation $\mathrm{Z}$ will select robots).

Another important point needs to be addressed. A typical fintech startup is formed under a specific project. The result of the project may be new technology, an improvement in an existing technology or process. Often the result is the release of an application to perform a specific function. Taking into account the large number of fintech companies, often the global nature of their operations, the number and range of their services are large and varied. Often, consumers are unable to understand the functionality of the services or evaluate their usefulness for themselves. This trend is likely to continue in the near future. Instead, traditional financial institutions, such as banks or insurance companies, have operated for hundreds of years and are understandable to most consumers.

The fintech industry passport can be represented as follows (Table 1).

The banks are the largest fintech investors in developed countries. In the USA, the picture is as follows (Figure 2).

CEOs of the largest US banks see major protection against competition in investing in fintech companies. Banks are particularly interested in new payment technology, investment transactions and Big Data analysis. It is significant, blockchain technology has less interest in traditional banking institutions. Recently, in the expert environment, it is often thought that this technology is not well-developed for practical use in the field of finance.

\section{Development trends of digital finance in Ukraine}

According to the Ukrainian Fintech Association, Ukrainian banks not investing in fintech startups [8]. This distinguishes the Ukrainian financial market from the developed countries' markets of the world.

Today, two different models of financial services are being formed: traditional and technological. It should be noted that there is bound to be a competitive situation in at least some segments of the financial market.

The question arises: In which field competition between financial institutions will intensify and where fintech companies have a chance to gain an edge over traditional banks. A clear answer to the question is provided by the statistics of fintech investments (Figure 3).
Table 1. Fintech industry passport in 2019 [5, 6].

\begin{tabular}{|c|c|}
\hline Indicator & Characteristic \\
\hline Availability & $\begin{array}{l}\text { Fintech market share across } 48 \text { fintech unicorns } \\
\text { deserves over } \$ 187 \text { billion as of the very first half } \\
\text { of } 2019 \text {, or slightly over } 1 \% \text { of the global } \\
\text { financial industry. } \\
\text { Fintech has reached an investment of } \$ 55.3 \\
\text { billion in } 2019 \text {. China's share of the rate is } \$ 25.5 \\
\text { billion, of which more than half ( } \$ 14 \text { billion) is } \\
\text { from Ant Financial of Alibaba Group, known for } \\
\text { its Alipay mobile payment service. } \\
\text { Return on investment in Fintech projects } \\
\text { averages } 20 \% \text {. }\end{array}$ \\
\hline Opportunities & $\begin{array}{l}\text { Blockchain can reduce regtech costs by } \$ 4.6 \\
\text { billion annually. } \\
\text { Increasing public access to variety of financial } \\
\text { services without the involvement of traditional } \\
\text { financial institutions, especially in developing } \\
\text { countries. } \\
\text { The availability of credit, investment and } \\
\text { insurance through fintech programs will meet } \\
\text { consumer and micro-enterprise needs. } \\
82 \% \text { of traditional financial institutions are going } \\
\text { to partner with fintech startups in the next } 3-5 \\
\text { years }\end{array}$ \\
\hline Potential & $\begin{array}{l}\text { Fintech has a CAGR of } 25-30 \% \text { over the forecast } \\
\text { period } 2019-2025 \text {. } \\
\text { Blockchain and regtech (regulatory technology) } \\
\text { are the fastest growing segments of the fintech } \\
\text { industry. } \\
\text { P2P or digital lending, another segment of } \\
\text { fintech, has a value of } \$ 43.16 \text { billion in } 2018 \text { and } \\
\text { one is expected to grow to } \$ 567.3 \text { billion. }\end{array}$ \\
\hline Threats & $\begin{array}{l}\text { Banks can lose } \$ 4.5 \text { trillion in the payments and } \\
\text { funds transfer market. } \\
\text { Closure of traditional financial institutions } \\
\text { branches due to fintech offensive with } \\
\text { corresponding job cuts. } \\
\text { The chaotic increase in the number of services } \\
\text { provided by fintech companies, the increase in } \\
\text { competition within the fintech, which will } \\
\text { worsen customer service as a whole. }\end{array}$ \\
\hline
\end{tabular}

The basis of modern fintech is the technology of making payments and transferring money. It is direction most sought after by consumers of financial services. Consumers have the highest number of complaints to traditional banks about the duration transfer of funds and the high commission.

Banks receive a large enough commission for these operations. The commission share in total income of Ukrainian banks is illustrated in Table 2.

There are restrictions on cash payments, and businesses and entrepreneurs are required to open a bank account for non-cash payments when registering in most part of the world. This has advantages for the existing banks over other economic entities. For instance, banks have a source of funding for commission, even during the financial and economic crisis, when the business activity's level dropped. Some banks are raising the commission at this time.

The high commission rates are explained by the usual desire to make a profit and the need to finance the banking infrastructure where the highest costs are associated with maintaining offices. 


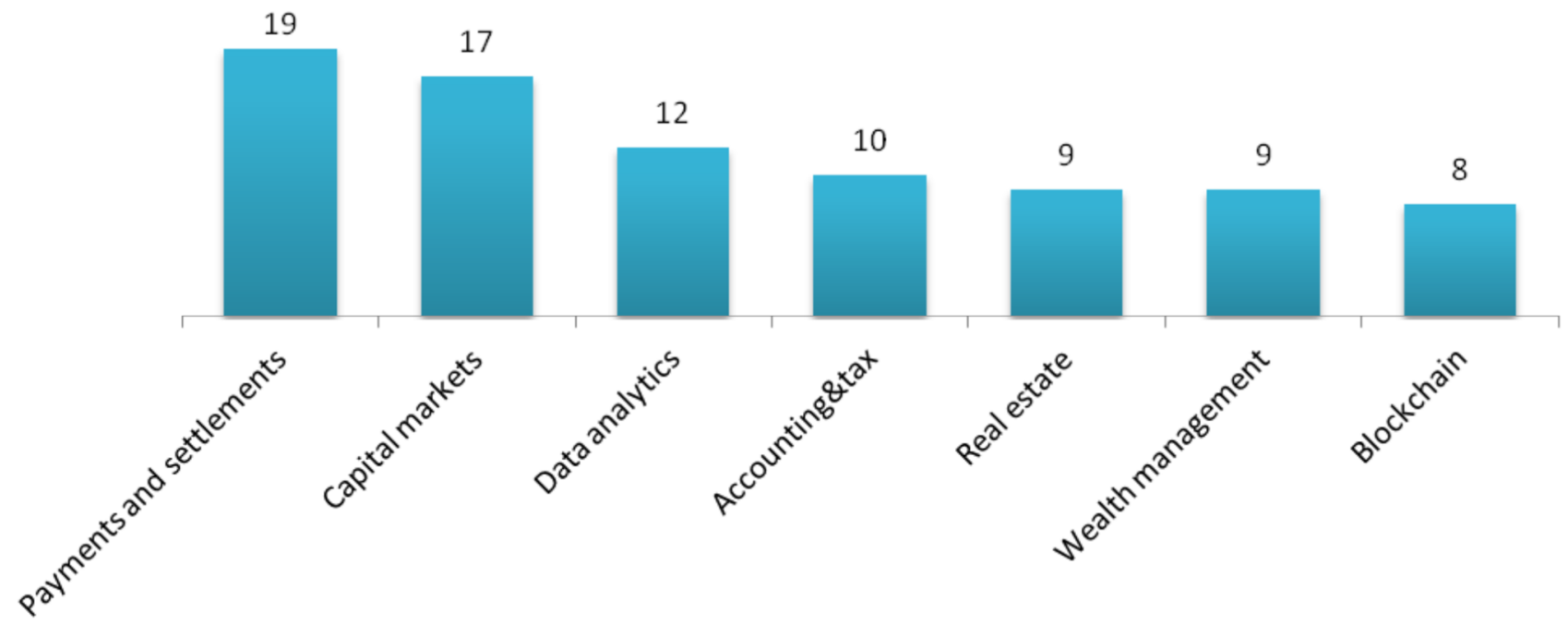

Fig. 2. Top US fintech startup segments, by number of US bank investors [7].

Alternative financing
Alternative lending
Personal finance
Digital payments

$\$ 20,00$

Fig. 3. Top fintech segments by transaction value, in millions [7].

Table 2. Share of commission in the income of Ukrainian banks (January-November 2019), mln. UAH [9].

\begin{tabular}{|c|c|c|c|c|c|c|c|c|c|c|}
\hline Rate & $\begin{array}{c}\text { January- } \\
\text { February } \\
\mathbf{2 0 1 9}\end{array}$ & $\begin{array}{c}\text { January- } \\
\text { March } \\
\mathbf{2 0 1 9}\end{array}$ & $\begin{array}{c}\text { January- } \\
\text { April } \\
\mathbf{2 0 1 9}\end{array}$ & $\begin{array}{c}\text { January- } \\
\text { May 2019 }\end{array}$ & $\begin{array}{c}\text { January- } \\
\text { June } \\
\mathbf{2 0 1 9}\end{array}$ & $\begin{array}{c}\text { January- } \\
\text { July 2019 }\end{array}$ & $\begin{array}{c}\text { January- } \\
\text { August } \\
\mathbf{2 0 1 9}\end{array}$ & $\begin{array}{c}\text { January- } \\
\text { September } \\
\mathbf{2 0 1 9}\end{array}$ & $\begin{array}{c}\text { January- } \\
\text { October } \\
\mathbf{2 0 1 9}\end{array}$ & $\begin{array}{c}\text { January- } \\
\text { November } \\
\mathbf{2 0 1 9}\end{array}$ \\
\hline Income & 39279 & 58012 & 77064 & 98854 & 121064 & 141401 & 164990 & 183996 & 201037 & 222073 \\
\hline Commission & 9164 & 13968 & 18939 & 24338 & 29114 & 34754 & 40047 & 45440 & 50687 & 56073 \\
\hline $\begin{array}{c}\text { Share of } \\
\text { commission }\end{array}$ & 23,3 & 24,1 & 24,6 & 24,6 & 24,0 & 24,6 & 24,3 & 24,7 & 25,2 & 25,3 \\
\hline
\end{tabular}

Fintech companies have the opportunity to provide low-fee services because they do not have offices or spend money to maintain them. In addition, fintech companies can generate value through related services (advertising, consulting, cross-selling and accompanying sale). An illustrative example is the transaction using the distributed registry technology, which took place on December 6, 2014: the $\$ 81$ million transaction was carried out immediately, in real time, for 4 cents [10].

In addition to the high commissions, the speed of transactions by traditional banking institutions deserves comprehensive criticism. It takes several days to transfer money to another country through SWIFT. Fintech companies often offer real-time transactions.
Thus, the field of payments and transfers of funds is a segment in which banks can lose to fintech companies, if they do not make any changes in their technologies.

M-PESA payment and transfer operator and Kenyan banks is the prime example. M-PESA is Africa's most successful mobile money service. It provides access to financial services to the millions of people who have a mobile phone, but do not have or have only limited access to a bank account. M-PESA provides people with a safe, secure and affordable way to send and receive money, topup airtime, make bill payments, receive salaries, get a shortterm loan and much more. Established on 6th March 2007 by Vodafone's Kenyan associate, Safaricom, M-PESA is Africa's leading mobile money service, with over 37 million active customers and almost 400,000 active agents 
operating across 7 countries: the Democratic Republic of Congo, Egypt, Ghana, Kenya, Lesotho, Mozambique and Tanzania.

In the Fiscal Year 2019, 37 million active customers carried out over 11 billion transactions, averaging over 500 transactions every second in December 2018 [11].

M-PESA has gained considerable success immediately since its introduction. This was manifested in the rapid growth in the number of system subscribers. Soon enough, Kenyan banks realized that a new competitor was actually jeopardizing their payments and money transfer business. A mega conflict arose at the end of 2008. Banks set themselves the task of completely eliminating a competitor. But M-PESA had in fact been belonged to the state, which resolved the conflict in its favor.

In the face of a multipronged onslaught from Kenyan Banks, M-PESA is not done proving its worth as the leader and innovator in offering mobile phone-based financial services.

M-PESA had at launch secured the full backing of the banking industry regulator in Kenya, the CBK, with its promise to deepen access to financial services in Kenya. While the delivery of M-PESA initially relied on Safaricom's dealer network, and later independent MPESA agent networks, banks in Kenya moved to embrace M-PESA, if only to gain access to Safaricom's ever-widening subscriber base, a good percentage of whom were using M-PESA to conveniently perform financial transactions.

It is now clearly emerging as no secret that while banks started to embrace M-PESA in 2009, integrating their services with the former, they had their product development teams working overtime to develop mobile banking and mobile money platforms of their own, several of which have been launched this year.

Prior to this, when Kenyan banks woke up to the realization that M-PESA's strength was in its ubiquitous agent network offering cash-in/cash-out services, they moved to develop partnerships with retail outlets in an agency banking model approved and passed by the CBK in 2010. In what can be seen as good business foresight, M-PESA had made its agency contract with M-PESA agents exclusive, meaning M-PESA agents were off limits to banks as agency banking outlets.

Equity Bank, as the largest bank in Kenya by customer base, came close to unlocking this exclusivity when it partnered with Safaricom to launch M-KESHO in 2010. M-KESHO is a service that allows deposits to, and withdrawals from, one's Equity bank account through selected M-PESA agents and through the MPESA menu. M-KESHO reached over 600,000 customers in a record 3 months, but unresolved teething pains prevented M-KESHO from replicating M-PESA's viral success.

While agency banking was instrumental in spreading banking services, the convenience of having one's money secured in a mobile phone 24 hours a day still gave M-PESA, and other mobile money transfer services that followed a big advantage [12].

Credit operations are brought the highest income to banks, and deposits of individuals and ones of legal entities are a resource base for them. Banks are practically protected from competition in this direction. You must have a banking license to conduct credit and deposit transactions. License requirements are set out in the Regulation on Bank Licensing [13].

The requirements are very stringent both in terms of material and financial resources and staffing. There are no fintech companies in Ukraine that which could be licensed and would be able to conduct deposits and lending operations.

But there are other situations in the world. For example, China is leading the digital banking world because of the launch of full-fledged digital banks called WeBank and MyBank. Tencent's social network and Alibaba's online store became founding members of the banks. The banking license was issued in 2015, but was restricted: banks were not allowed to open offices and receive deposits. Thus, the authorities tried to keep these banks from directly competing with state-owned banks. These banks, at the beginning of their development, have focused their efforts on Chinese residents who did not have bank accounts and access to financial services [10].

There is a two-tier banking system worldwide, where the first tier is represented by the central bank and the second level by commercial ones (state and non-state ownership). For a long time, such system is the basis for the monetary system functioning in a market economy. Thanks to this system, governments can impact on money supply, credit activity and business one, and inflation. Accordingly, governments will protect this system from uncontrolled changes that may disrupt equilibrium. On the part of the state, there are fears that an ever-increasing number of poorly controlled fintech companies will cause chaos in the financial market. After all, they generate a large number of projects in the area of money, credit, deposits, investment operations and insurance. Therefore, banking license availability protects banks from competition from fintech companies in the most important segment of deposit and credit segment.

Banks may be interested in working with microfinance fintech companies as well. This area is of little interest to banks because of the difficulty in administering (by current banking technologies) and low profits. Fintech companies can make money in this area because they have new technology management capabilities that are mobile and personalized, and they do not have to spend on maintaining the banking infrastructure.

P2P lending plays a considerable role among the alternative to traditional banking technology. P2P stands for peer-to-peer or person-to-person lending, which means peer lending. In other words, it is lending to an individual by an individual [14].

The pioneers in P2P lending world were the United Kingdom and the United States. The first such site was created in 2005 and provided exclusively for consumer loans. Today, the range of available loans is not limited to anything, large companies are coming to online sites, and the need for corporate financing is increasing.

Experts note the popularity of this area. So, in 2012, a few years after the big financial crisis, the global volume of P2P lending was about $\$ 1.2$ billion. In 2017, analysts called the figure $\$ 64$ billion. And according to Morgan Stanley, 
by 2020 the market will reach $\$ 300$ billion. Since 2016, this financial sector has begun to soaring - by $53 \%$ year over year. This can be explained by the increase in requests for P2P lending from SMEs. Now, analysts are talking about $120 \%$ of the annual average increase. And there is no reason to stop now [15].

Based on the content of P2P lending, it should be noted that it will be much cheaper, because one of the components of the banking interest is the cost of maintaining the banking infrastructure. P2P lending is otherwise called peer-to-peer lending. As the name implies, borrowers and investors are often individuals. At the same time, there is no intermediary (bank) between them, which allows to set adequate interest rates, determine the optimal deposit sum, establish favorable loan servicing conditions and avoid large commissions. Small percentages and commissions are also achieved by the fact that there is practically no administrative staff in the classic P2P lending scheme or crowdfunding and the office is replaced by a digital platform (Figure 4).

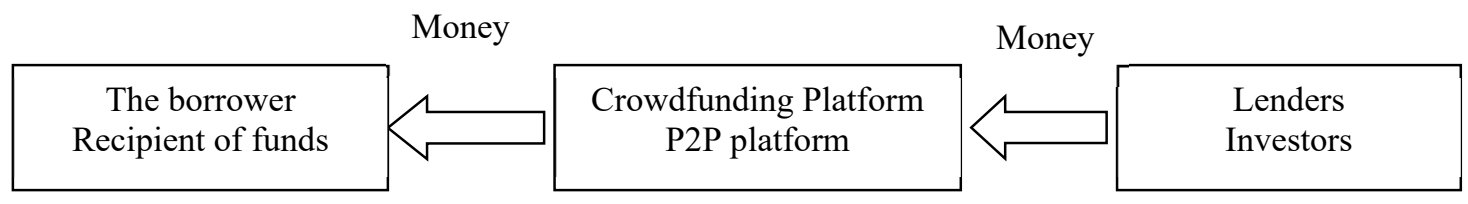

Fig. 4. Traditional P2P lending and crowdfunding scheme (mediation is not required).

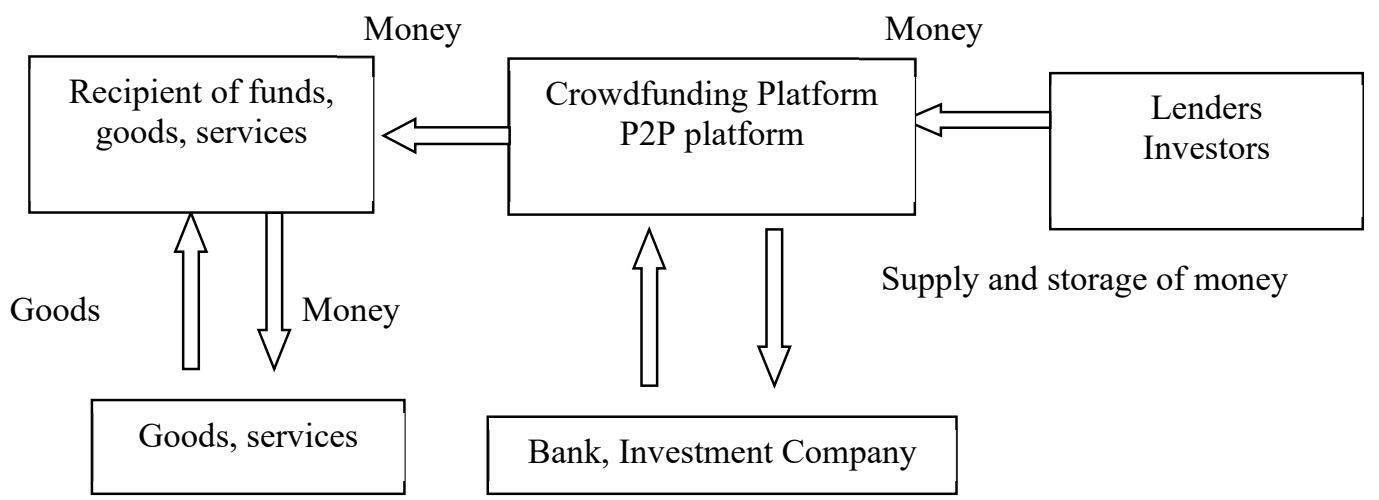

Fig. 5. P2P lending and crowdfunding scheme where the bank or investment Company is a partner.

Fintech companies have limited opportunities to enter the crowdfunding market in Ukraine. The limitation is due to two factors. The first factor is psychological. Public confidence in the banking system is still low and the more recent fintech companies (an absolute majority of the population know so little about both fintech companies as a phenomenon and the services offered by fintech).

Modern Ukrainian history is a history of crises, including financial crises. It is worth mentioning that in the collapse of the USSR, the overwhelming majority of Ukrainians lost their savings completely, which were retained in the accounts of the State Bank and the State Insurance Company. Already in recent Ukrainian history, people had been losing money in the financial pyramids of 1993-1994, as a result of the crisis in the financial system in 1998, due to the factors of the impact of the global crisis of 2008 and after the crisis caused by
Under this scheme, a fintech company that has created and presented a digital platform is in charge of managing the whole process and thus becomes a competitor to traditional banks or investment companies. But there are several problems. The first problem is trust in the platform and the fintech company to ensure the process of saving money. The second problem is the lack of funds raised through the platform to achieve the goal of the process. In either case, traditional banks or an investment firm can become partners and solve both problems. A bank can act as a guarantor of saving money or provide the missing amount on favorable terms.

An illustrative example is the Brazilian Banco Original, which provides crowdfunding for the purchase of new cars in order to provide its customers with discounts and favorable credit [10].

The bank has the resources to buy a large batch of cars, which will provide it with a discount from the manufacturer, and a crowdfunding platform provides customers. Buyers also become bank customers (Figure 5). 
Data, provide the ability to personalize the needs of most members of social networks.

In October 2018, the number of regular Internet users in Ukraine was $63 \%$ of the population (20.8 million people). According to a Factum Group Ukraine poll, $70 \%$ of regular users use a smartphone to access the Internet. According to a survey by the Research \& Branding Group, in early 2019, more than half of Ukrainians (55\%) had already a device like a smartphone, while $45 \%$ had not yet purchased one. In March 2019, Facebook was the most popular social network in Ukraine, used by $50 \%$ of respondents. Research data from Research \& Branding Group show this. According to sociologists, since May 2018 in Ukraine the number of social networks users such as Facebook (up to $50 \%$ ), YouTube $(30 \%)$, Instagram (27\%) has significantly increased and the number of social network users such as Classmates $(6 \%)$ and VK $(10 \%)$ has slumped [16].

20-25 million Internet and social network users are significant opportunities for traditional financial institutions such as banks, insurance companies and fintech companies. In fact, these are real and potential consumers of financial services.

It is now possible to distinguish two leaders in digital adoption in banking. The first is the state-owned CB "Privatbank" whose payment system "Privat 24" is very popular among population: at the beginning of 2020, 10 million Ukrainians used this app [17].

The Bank has more than 20 thousand terminals and ATMs and 6440 thousand depositors. Among additional banking services that are in demand among consumers are the purchase of tickets for transport; calling a doctor; repayment of a part of the spent money on bonus programs, purchase of domestic government bond. Recently the bank has launched an online purchase service. Once purchased, product will be stored securely at the bank.

CB "Privatbank" implemented a very interesting (and today unique in the bank insurance) project until nationalization, which took place in 2016. The Bank was founded the insurance company PJSC "Ingosstrakh". Initially, it employed 38 people, the company had no offices. All insurance services were provided exclusively in electronic format, and CB "Privatbank" was the only agent of this company. The project was a huge success. For two years, the company entered the TOP 5 Ukraine insurers by volume of insurance premiums received (first place in 2016 by premiums in accident insurance). As a matter of fact, the project abolished the ban on banks to engage in insurance activities that has been operating in the EU and Ukraine. The project was curtailed after the bank nationalization.

On the example of CB "Privatbank" we can see a combination of financial and non-financial operations. It is this business model is likely to be trending in the coming years.

The second technological leader in banking is the TAS financial group. The Group combines assets in industry, agriculture, development, banking and insurance. In November 2017, some of the executives of CB "Privatbank" (the nationalized bank at that time), have founded the Fintech Band and have developed the Monobank app. One is positioned as a bank without offices. In fact, it is Universal Bank's retail product (it was founded in 1994, and since December 3, 2016 it is TAS group part), which originated in cooperation with the Fintech Band team. Credit cards for customers, deposits and other services are issue taking place within Monobank. The best mobile app makes managing customers' finances as convenient as possible. Monobank only works on mobile devices. The Fintech Band team employs more than 100 people, mostly from PrivatBank.

Monobank's investment amounted to \$2 million, which the Fintech Band expects to return in one to two years. The Fintech Band is going to get their money back and make a profit as follows: to sell its platform and complex of accompanying services to other market players. The company has already made deal with two banks. Initial investment in the Monobank project draws attention by a small amount, even by Ukrainian standards (\$ 2 million). It should be added that most users consider Monobank services to be a bank and not Universal Bank's structural unit [18].

The first attempt to launch the P2P lending platform in Ukraine was made by CB "Privatbank" together with MasterCard in 2016. The new non-standard service launch can be regarded as a publicity stunt, due to the situation with Privatbank was very tense and difficult at that time.

Its purpose was to show that the bank is fine. After the nationalization of the bank, the program was curtailed.

FinHub has become the first platform of direct P2P lending without intermediaries in Ukraine. The company was able to create a high-end service that is a real alternative to traditional lending, based on a study of the world's best experiences of successes and mistakes. Secure payment processing using the latest technologies is carried out jointly with partners TASLink and JSC "TASCOMBANK".

FinHub offers its borrowers:

- it is possible to draw long-term (up to 15 thousand UAH up to 1 year) or short-term (up to 5 thousand UAH up to 30 days) credit;

- the cost of credit is much lower compared to online credit services and banks;

- there is no need to leave the house - the application process, scoring and accrual takes place online;

- only the passport and ID code are required for registration;

- there are no hidden payments, commissions, etc.;

- the loan repayment is also held online through the personal cabinet.

Investors benefit from work with FinHub because:

- it is a real modern and easy way to increase your income (up to $300 \%$ per annum);

- a large number of applications diversify risks;

- the sum of investments starts from $500 \mathrm{UAH}$;

- unscrupulous borrowers are eliminated at FinHub's automatic scoring stage;

- credit applications have all the key data (sociodemographic parameters, income levels, etc.) available to build a carefully thought out investment strategy [15].

It immediately attracts the attention that investors are offered earnings up to $300 \%$ per annum. The question 
arose: How much should the borrower pay and whether such a loan is needed?

In Ukraine, P2P schemes and crowdfunding ones cannot gain rapid distribution. The options described are rather image samples of well-known market players in the traditional banking sector. Transformations caused by digital technologies can also occur within the financial institution itself. The Polish BRE Bank story, which was founded the mBank unit in 2000 to provide on-line services, is striking (it looks like the Ukrainian Monobank name is not fully original). Thanks to mBank launch, this bank has become Poland's largest online bank and the third largest retail bank. Due to its success, mBank in 2007 has expanded its operations to the neighbors markets - the Czech Republic and Slovakia. Having analyzed the success story of BRE Bank in 2013, it decided to rebrand the entire bank under the name mBank based on four principles: real-time marketing; personal financial management; mobile banking; social media [19].

Consequently, there are a lot of options for financial institutions transformations related to digital technologies. There can be no single templates. But not one financial institution is likely to can ignore the new realities.

Talking about finance and technology, one should not overlook the issue of cyber risk. Cyber risks are the risks that arise from the use and transmission of electronic data, including technological tools such as the Internet and telecommunications networks [20].

Cyber risks are consistently in the top 10 risks to humanity. The use of digital technologies in finance not only provides new opportunities, but also activates cyber threats in the form of unauthorized access to financial services of consumers' personal data. Not only personal data, but also real money of clients is threatened with theft.

Cyber-risk protection requires significant investment in security systems. Often, this is beyond the power of small fintech companies and new startups. Traditional financial institutions have a systematic approach and resources the struggle against cybercrime and this is a significant competitive advantage.

\section{Conclusions}

The financial ecosystem is changing rapidly under the influence of digital technologies. A new financial institutions layer, a fintech company, has emerged and is actively developing. New fintech companies compete with traditional banks and payment systems in areas such as payments and money transfer. But fintech companies are not competitors of banks in the traditional sense, because their share in the global financial market does not exceed $1 \%$, despite its rapid growth in recent years.

The governments of the countries are interested in maintaining the traditional structure of the financial market, the two-tier banking system, as it protects the monetary system from chaos. Business and household confidence in banks is much higher than in fintech companies, despite the crisis events in the 2008-2009 (and in 2014-2016 in Ukraine). Banks have resources to world protect customers' information and money from all kinds of cyber risks.

In 2019, fintech investment has decreased. This can be associated with the market saturation digital financial services, many of which are complex and incomprehensible to consumers. The growth of the fintech sector can be expected in the insurance and private investment sectors, which are not as tightly regulated as the banking sector.

In general, traditional financial institutions and new fintech companies are doomed not to compete but to cooperate. Traditional financial institutions need new technologies, and financial companies need investment.

\section{References}

1. Global analysis of investment in fintech, Pulse of Fintech 2018, KPMG International (9 July, 2018), https:/home.kpmg/xx/en/home/insights/2018/07/puls e-of-fintech-h1-2018.html. Accessed 15 Feb 2020

2. Global analysis of investment in fintech, Pulse of Fintech 2019, KPMG International (30 July, 2019), https:/home.kpmg/xx/en/home/campaigns/2019/07/p ulse-of-fintech-h1-2019.html. Accessed 15 Feb 2020

3. Biannual global analysis of investment in fintech, Pulse of Fintech 2019 (31 July, 2019), https:/home.kpmg/ua/ru/home/insights/2019/08/pulse -of-fintech-h1-2019.html Accessed 15 Feb 2020

4. Zachem kitajskij strahovshhik Ping An Insurance investiruet \$22 mlrd. v razlichnye startapy (Why Chinese insurer Ping An Insurance invests \$ 22 billion in various startups) (Forinsurer, 2019), https://forinsurer.com/news/19/11/07/37373. Accessed 17 Feb 2020

5. Global fintech report Q2 2019, https://fintek.pl/wpcontent/uploads/2019/08/CB-Insights_FintechReport-Q2-2019.pdf. Accessed 16 Feb 2020

6. FinTech Market Accelerating the Development of Ecommerce Industry (2019), https://www.industryarc.com/PressRelease/685/FinTe ch-Market-Research.html. Accessed 16 Feb 2020

7. Nestor Gilbert. 79 Key Fintech Statistics 2019 \& 2020: Market Share \& Data Analysis (2019), https://financesonline.com/fintech-statistics. Accessed 17 Feb 2020

8. M. Jarovaja, Usi fintekh-kompaniji Ukrajiny, pochynajuchy z 1991 roku (All fintech companies in Ukraine since 1991). (Ain.ua, 6 July, 2019), https://ain.ua/2019/07/16/ukrainsrij-fintech-2019. Accessed 17 Feb 2020

9. Financial Stability Report. (NBU, December, 2019), https://bank.gov.ua/news/all/zvit-pro-finansovustabilnist-gruden-2019-roku. Accessed 17 Feb 2020

10. K. Skynner. ValueWeb: Kak finteh-kompanii ispol'zujut blokchejn $i$ mobil'nye tehnologii dlja sozdanija interneta cinnostej (ValueWeb: How fintech firms are using bitcoin blockchain and mobile 
technologies to create the Internet of value). (Mann, Ivanov i Ferber, Moskva, 2018)

11. What is M-PESA. (Vodafone, 2019), https://www.vodafone.com/what-wedo/services/M-PESA. Accessed 17 Feb 2020

12. Kenyan Banks vs. M-PESA: the gloves come off, https://www.mobilepaymentstoday.com/blogs/ken yan-banks-vs-M-PESA-the-gloves-come-off. Accessed 17 Feb 2020

13. Resolution of NBU Board on approval of the Regulation on Bank Licensing №149 (22 Dec 2018). Oficijnyj visnyk Ukrajiny 12, 149 (2019)

14. O.V. Krukhmalj, E.V. Krukhmalj, O.S. Zajecj, Peer-to-Peer kredytuvannja v Ukrajini perspektyvy rozvytku ta vyklyky dlja bankiv (Peer-to-Peer Lending in Ukraine: Development Prospects and Challenges for Banks). International scientific journal 2, 93-96 (2017)

15. V Ukrajini z'javylasja persha platforma P2Pkredytuvannja (Ukraine has launched its first P2P lending platform) (MFU, 22 February, 2019), https://minfin.com.ua/ua/2018/02/22/32462749.

Accessed 18 Feb 2020

16. Skladeno rejtyngh populjarnosti socialjnykh merezh $\mathrm{v}$ Ukrajini (The rating of popularity of social networks in Ukraine has compiled) (RBKUkraine, 12 April, 2019 ), https://www.rbc.ua/ukr/news/sostavlen-reytingpopulyarnosti-sotsialnyh-1555070035.html. Accessed 18 Feb 2020

17. Official web-site CB PrivatBank, https://privatbank.ua/. Accessed 18 Feb 2020

18. M. Olijarnyk, Bank u smartfoni. Jak i dlja chogho kolyshni "pryvativci" stvoryly Monobank (Bank in smartphone. How and why the former "private" created a Monobank). (NV, 11 Nov 2017), https://nv.ua/ukr/techno/made-in-ukraine/bank-usmartfoni-jak-i-dlja-chogo-kolishni-privativtsistvorili-monobank-2180292.html. Accessed 18 Feb 2020

19. K. Skynner, Cifrovoj bank. Kak sozdat' cifrovoj bank ili stat' im (Digital Bank: Strategies to Launch or Become a Digital Bank). (Mann, Ivanov i Ferber, Moskva, 2015)

20. CRO Forum. The Cyber Risk Challenge and the Role of Insurance (Dec 2014), http://www.thecroforum.org/cyber-resiliencecyber-risk-challenge-role-insurance. Accessed 03 Mar 2020 